\title{
Review of methods for climatic zoning for building energy efficiency programs
}

\author{
A.Walsh ${ }^{1}$, D. Cóstola ${ }^{2}$, L. Labaki ${ }^{1}$ \\ 1 - UNICAMP State University of Campinas, Brazil \\ 2 -University of Strathclyde, Scotland, United Kingdom
}

\begin{abstract}
Climatic zoning is an essential element of most building energy efficiency programs, however there is no widely accepted scientific technique for its delineation. This paper reports an investigation on this issue, which comprised the review of climatic zoning methodologies for building energy efficiency programs adopted by 54 countries. The paper identified that the nature and magnitude of climatic variations are not the main elements in the definition of the number of climatic zones in a country. The number of climatic zones seems to be mainly driven by the expected simplicity of the final climatic zoning, respecting in most cases a maximum of 8 zones independent of the country size and climatic variations A total of 19 different variables, techniques and parameters used in climatic zoning were identified, the most frequent being temperature, degree days, altitude, administrative divisions and relative humidity. However, around $80 \%$ of the countries analysed in this study used only up to three variables/techniques/parameters to define their climatic zoning. This simplicity comes at the cost of ignoring several aspects of climate and building energy performance. From the techniques identified in this review, only the combination of building performance simulation and cluster analysis seems to provide robust tools to tackle the complex relations between climate and building energy performance. Combined, these tools may provide the means to explore scenarios and support evidence-based decision making in energy policy. The lack of consensus in several aspects of climate zoning indicates the need for further research in this area.
\end{abstract}

Keywords: Climatic zoning, building energy efficiency, building climatology. 


\section{Introduction}

The large influence of climate on building thermal performance has been known for millennia [1-3]. However, only in the second half of the last century have researchers tackled the definition of climatic zones specifically for building energy efficiency programs [4-7]. In this context, a climatic zone is usually understood as a region on the Earth's surface where climatic variables have small variation, allowing the use of uniform recommendations or mandatory values for certain building characteristics throughout the whole area within the climatic zone [8,9]. These recommendations or mandatory values are central elements of most building energy efficiency programs [10], stressing the important role of climate zoning in the achievement of ambitious goals for energy security, reduction of greenhouse effects to reduce the pressure on climate change, etc.

Climate zoning was not initially developed for building energy efficiency programs. Early climate classifications, dating from 1900, were general-purpose [11,12]. Those classifications were based on the identification of climate patterns related to vegetation and gave rise to one of the most well-known climatic classifications, the Köppen system [13]. In subsequent years, many other climate classifications were developed for agriculture and other specific domains, including climate classifications in building energy efficiency programs.

Early initiatives on climatic zoning for building energy efficiency programs date from 1949-1960 and were conducted mainly in heating dominated countries with extreme weather conditions [5-7]. Today, several countries in the world are subject to climatic zoning for analysing energy efficiency in buildings [9,14-19]. These climatic zones are used for various purposes, supporting thermal regulations with prescriptive-based and performance-based requirements [20,21], standardized data for building energy calculation [22,23], energy standards [24], voluntary labelling programs [25], and design guidelines [26].

The definition of adequate climatic zones is a complex task due to the interaction of several independent variables. Due to this complexity, climatic zoning for building energy efficiency programs is usually developed by ad hoc studies, where a variety of methods have been used [24]. A brief survey on the topic revealed large variations in the climatic zoning methodology used by different countries, ranging from simplified calculations using steady-state heat transfer [27] to complex dynamic simulations of heat, air and moisture in buildings and heating, ventilation and air-conditioning systems (HVAC) [20]. It is remarkable that so many methodologies have been used, indicating the lack of consensus regarding the appropriate methodology to conduct climatic zoning for building energy efficiency programs. The large number of new climatic zones published in the last 10 years also indicates the relevance of this topic for the public, government and research community $[9,20,28-31]$.

Previous review papers on this topic provided, at the time of their publication, valid overviews of climatic zoning methodologies for a few specific regions of the world $[19,24]$. These overviews addressed only a few climatic zoning 
methodologies and have been published more than 10 years ago. To the knowledge of the authors, there is no comprehensive and up-to-date review of the methods for climatic zoning for building energy efficiency programs. This paper aims at filling this gap by providing a thorough review of climatic zoning in fifty four countries, responsible for more than $85 \%$ of the world primary energy consumption [32] and representing approximately $71 \%$ of the world's population.

The paper is structured in 4 sections, as follows. Section 2 describes the selection of countries included in this review and the criteria adopted in the selection of supporting documentation for each country. Section 3 provides a general description of the adoption of climatic zoning over the world. Section 4 summarizes the main conclusions of this review and proposes a road map for the research on this topic.

\section{Materials and methods}

This study was performed by surveying national and international building codes, standards, scientific papers and other documents related to building energy efficiency programs. Approximately $90 \%$ of the cases reviewed in this paper are related to normative documents found mainly in international databases from entities such as the International Energy Agency (IEA), Energy Performance of Buildings Directive (EPDB), United Nations Environment Programme (UNEP) and Pacific Northwest National Laboratory (PNNL) among others. A small fraction (10\%) is composed of academic research with no legal effect in their countries.

Queries using internet search engines were conducted using a wide range of keywords related to climatic zoning. The initial survey was carried out in English, Spanish, French and Portuguese, so only documents in these languages were initially included. Reference lists of documents identified in the initial survey were also used to identify documents related to climatic zoning; these documents were then reviewed independent of their language. Whenever possible, primary sources were identified and used as main source of data for this review.

There was considerable variation in the available information on the climatic zoning methodology adopted by each country. In some cases, there was only a brief description of zones, with no information about the method employed; these cases were not included in this review. Only the most recent climatic zoning was considered for each country. Some countries adopt different methodologies for climatic zoning for different seasons of the year or for different building energy regulations; in these cases each zoning was considered as an independent entity for this review.

Once the climatic zonings were identified and reviewed, the analysis of methodologies for climatic zoning was carried out country by country. This analysis consisted of the identification of parameters, climatic variables and/ or techniques used in the climatic zoning. The frequency of occurrence of each parameter, climatic variable and technique across the climatic zoning methodologies was calculated, providing the core data for this paper. Data on the combination of parameters, climatic variables and techniques were also compiled to cast light on the concomitant use of factors in 
methodologies for climatic zoning. A brief discussion about the relation between climatic zones, thermal comfort and building energy efficiency was also included.

The review does not address minor variations in similar methodologies for climatic zoning used by different countries. This simplification is consistent with the paper aim, i.e. the identification of patterns and trends in climatic zoning rather than detailed discussions of the methodology adopted by each country. Even though there is a strong correlation between the climate zoning and the corresponding energy requirement, this paper only addresses the methodologies for zoning, not considering the use of climatic zones for the establishment of building energy policies, recommendations and requirements.

\section{Climatic zoning for building energy efficiency programs over the world}

\subsection{Adoption of climatic zoning over the world}

The work based on the methodology described in Section 2 identified a total of 54 countries with climatic zoning for building energy efficiency programs. Some countries have more than one climatic zoning, resulting in this review addressing a total of 64 climatic zonings. Appendix 1 shows a list of countries and documentation used in the analysis. These countries are shown in Figure 1, representing 70\% of the world land surface and $71 \%$ of the world population [33] being responsible of $85 \%$ of the total primary energy consumption [32]. This initial finding highlights the importance and widespread use of climatic zoning nowadays. Many countries are not addressed by this study, as they may not have climatic zoning, or there was not enough information available about their climatic zoning in the languages covered by this study. These omissions should be clarified in future studies.

The analysis of documentation listed in Appendix 1 reveals that around $75 \%$ of the documents used in this review were published after the year 2000. The nature of documentation varies substantially (reports, standards, laws, guidelines), therefore the date of publication may not always precisely match the age of the climatic zoning in that particular country. In spite of some eventual imprecision, it is reasonable to say that a considerably large number of countries revised or introduced climatic zoning in the last 15 years. This intense activity on climatic zoning stresses the importance of this subject and it reflects the increasing awareness of countries on the importance of building energy efficiency programs. Nevertheless, the large variation of approaches adopted in the climatic zoning indicates the lack of a proven and widely accepted methodology, even after more than a half-century from early initiatives in this field [5-7,34]. 


\subsection{Amount of zones per country and variation in the extent of climatic zones}

Defining the number of zones necessary to capture climatic variation is an essential part of the climatic zoning process. Data collected in this review indicates no direct relation in the cases analysed between the number of climatic zones and the country area (Figure 2). On the one hand, small countries adopt zones with high resolution in space to address specific geographical, climatic or political divisions. On the other hand, large countries limit the amount of zones for practical reasons, sometimes ignoring what can be considered a small variation when compared to the size of the whole country. The correct number of zones necessary to characterize a country is essential to the success of any building energy efficiency program. An excessively high number of zones lead to overcomplicated building energy efficiency programs, making their use and adoption difficult. An excessively low number leads to extensive zones with large climatic variations within the zone, making them inappropriate for any building energy efficiency program.

Climatic zoning in the United States of America (USA) can be used to exemplify the challenges in the definition of the proper number of climatic zones. This large country has a national building code applicable to its whole territory, but it has also building regulations at state level addressing smaller fractions of its territory [35]. According to the International Energy Conservation Code [36] and the ASHRAE Standard 90.1 [37], the USA is divided into 17 zones (Figure 3b). The low resolution national climatic zoning of the USA is contrasted by the climatic zoning in the State of California, where large efforts in energy efficiency have been implemented in the recent past. The State of California has a higher resolution climatic zoning containing 16 zones [38] (Figure 3a), with climate zones defined by energy use [21]. The average area per climatic zone varies by a factor of 20 between these two climatic zoning schemes, from $26.10^{3} \mathrm{~km}^{2}$ in California State to $5.10^{5} \mathrm{~km}^{2}$ in the USA nationwide classification.

Tunisian climatic zoning can also be used to exemplify the complexity in the definition of the number of zones needed. This country has two climatic classifications, one for thermal regulation purposes (with three zones) and another for passive building design guidelines (with ten zones) (Figure 4). Both climatic zoning schemes were developed using the same method but the result was conditioned by the performance metrics adopted in each case (energy consumption in HVAC and thermal comfort in buildings with no HVAC respectively). As a consequence, the climatic zoning developed for thermal regulation purpose shows little sensitivity for some climatic variables, such as wind speed and direction. The one developed to establish passive design guidelines was strongly influenced by all climatic variables and other local particularities [39]. The average area per zone in these two climatic zoning classifications are in the same order of magnitude, ranging from $1.10^{3} \mathrm{~km}^{2}$ to $5.10^{3} \mathrm{~km}^{2}$, both much smaller than the average zone size in California.

The contrast between small and large states/countries can be further observed by the average area of each zone per state/country, which varies by a factor of around 3000 , ranging from approximately $10^{3} \mathrm{~km}^{2}$ to $1.810^{6} \mathrm{~km}^{2}$ (Figure $5 \mathrm{a}$ ). The bars representing the USA, California and Tunisia are highlighted in blue in this figure, where one can see they are 
representative examples of climatic zoning in small states/countries (such as California and Tunisia) and large countries (such as the USA). Figure 5a indicates a direct connection between area per zone and country size. Most countries adopt a similar total number of zones and simply divide its territory by this number. Figure $5 \mathrm{~b}$ shows that in $76 \%$ of the countries the number of zones varies very little, ranging between 3 and 8 . This is a small variation considering that the areas of these countries vary by a factor of around 3700. These data may indicate that practical reasons (and not climatic variations as one would expect) are the main driving forces in the definition of the number of zones, as 3 to 8 zones are easily manageable in building energy efficiency programs. These data indicate that some large countries may have oversimplified climatic zoning while some small countries may have climatic zoning which are excessively and unnecessarily complex.

Climatic zoning is usually adopted to guide requirements for the construction industry, having high economic impact. However, they are the target of strong criticism [31,40-44]. This criticism can severely delay the transition from voluntary to mandatory requirements in some countries, as for example in Brazil where climatic zoning took more than a decade to become part of building requirements $[14,45]$. An arbitrary number of zones may increase criticism, particularly in cases of neighbouring areas with similar climates, but located on opposite sides of boundaries between adjacent zones. Figure 6 exemplifies this situation, by highlighting a region of California State (zone 2 in state climate zoning) having areas placed in different climatic zones in the USA (zones 3B, 3C, 4B, 4D). Such neighbouring areas will face different construction requirements according to USA standards for zones 3B, 3C, 4B, 4D in spite of similar climates as acknowledged by the State zoning [40]. Another example of this situation can be found in the triple border of Argentina, Brazil and Uruguay, all countries with similar construction industry and economic development. Near this triple point, recommended U-values for roofs based on climatic zoning vary from 0.5 to $2 \mathrm{~W} / \mathrm{m}^{2} \mathrm{~K}$ depending on which side of the border the building is placed $[19,46]$, in spite of negligible climatic variations in this region.

From the discussion above, it is clear there is a need to adopt reliable methods for deciding the appropriate number of zones in the climatic zoning process. Nevertheless, little or no information about this decision is available in the documentation analysed for this paper. Findings indicate: (a) an interest in using a minimum number of zones to keep simplicity for regulatory provisions [8]. and (b) the pursuit of consistency between climatic zoning and other geographic features [24] which in extreme cases leads to climatic zoning matching administrative division [9]. It can be concluded that, at the moment, there is no scientific method widely accepted to deal with the trade-offs between complexity and accuracy in the definition of the number of climatic zones necessary in a country for a given purpose (e.g. regulation and design guidelines). 


\subsection{Purpose of climatic zoning}

Climatic zoning schemes for buildings have been created for a number of purposes. Independent of the purpose, most climatic zoning classifications started as academic or institutional research, going through a process of discussion and validation before being embedded in voluntary or mandatory regulations [24]. This process is conditioned by particularities of each country and the status of their building energy programs. In spite of these particularities, climatic zoning can be classified based on its purpose in three groups: performance-based requirements, prescriptive-based requirements and passive design guidelines (the frequencies of these three groups are indicated in Figure 7). The role of climatic zoning in these three groups is briefly discussed in the following paragraphs.

Performance-based approaches generally refer to the building as a whole, assessed using high-level indicators such as total energy consumption, energy cost and/or thermal comfort, and indoor air quality. This approach is more flexible than the prescriptive approach and promotes innovation in building energy efficiency programs [47]. In this study, $36 \%$ of the climatic zoning classifications were developed to support performance-based regulations, usually indicating maximum values for energy consumption or hours of discomfort for each zone for different building archetypes. Weather data for building energy assessment is established for each zone in order to facilitate and standardize the building energy calculation process. The cases of France [48] and Finland [49] illustrate this group.

Prescriptive-based approaches are frequently related to minimum (or maximum) values allowed for certain thermal properties of building envelope components, such as U-values, Solar Heat Gain Coefficient (SHGC) and Window-to-Wall Ratio (WWR), and Coefficient of Performance (COP) of HVAC systems. This approach is simple to implement and capable of providing significant energy saving in many cases. These advantages make the prescriptive-based approach widely used in building energy programs [50]. This wide use is also illustrated in this study as more than 50\% of climatic zoning classifications are associated with prescriptive-based approaches. Examples of this approach are China [51] and Greece [27].

A third group of climatic zoning schemes is related to passive design guidelines, taking advantage of natural resources to minimize energy use in buildings. These guidelines are usually associated with the building's shape, orientation, building envelope properties and passive heating/cooling strategies [52,53]. They are generally applicable in early design stages of the project, when the highest potential of building performance improvement occurs. This type of approach applies to around $14 \%$ of the cases analysed in this paper. Examples are Colombia [28] and Thailand [54].

\subsection{Relation with climatic zones, thermal comfort and building energy efficiency}

The relation between climatic zone and energy efficiency differs significantly among countries, as the weather is not the only driver of energy consumption in buildings [55]. In particular, buildings characteristics and technologies differs significantly throughout the globe impacting in the energy performance of buildings. In some countries, representative 
values of weather data for energy load calculation are established for each climatic zone, while buildings energy use and $\mathrm{CO}_{2}$ emissions should respect certain limit through all the country [22]. In other countries, there are specific performance targets for each climatic zone [48]. In France, for example, there is a maximum allowed annual consumption of primary energy of the building taking into account performances of HVAC system, domestic hot water (DHW) and artificial lighting which varies according to the climate zone [48]. In Morocco, a limit in HVAC demand is established for different archetypes and climatic zones expressed in $\mathrm{KWh} / \mathrm{m}^{2} / \mathrm{year}$ [20]. Morocco climatic zoning is based on building energy simulation, and results were used to demonstrate savings up to $73 \%$ (in energy needs for heating and cooling) due to the adoption of climatic zones and building recommendation [20]. The case of Morocco is the exception in climatic zoning as for most countries there is no information available on the relation between zoning and energy performance gains.

Climatic zoning in some tropical countries is driven by concerns on improving thermal comfort in the many buildings with no HVAC systems [14,45,56]. Climatic variables are post-processed using predesign tools, which are further discussed in sections 4.6 and 4.7 [29,57]. These tools compare climatic data with comfort requirements, supporting the definition of climatic zones and prescribing suitable building characteristics to maximize indoor comfort when there is no HVAC systems [58]. As thermal comfort preferences are climate reliant [59-61], the definition of the most adequate comfort zone and design guidelines depend on the context it is applied. For instance, as indicated in Figure 8, climatic zoning in northeast India was based in Milne and Givoni psychometric chart [57], while in Nepal, the thermal comfort zone for hot climates defined by Givoni was used instead [29]. In Brazil, climatic zoning was based in an adaptation of Givoni' s work [14]. The outcome of Brazilian climatic zoning have been target by criticism in face of the latest advances in thermal comfort research considering adaptive models $[62,63]$.

Thermal comfort indicators are also used as performance indicators in simulation-based climatic zoning (discussed in section 4.4). Building energy simulation programs provide a flexible approach and allow the use of several thermal performance indicators such as hours of discomfort above, a reference operative temperature, PMV values, the adaptive thermal comfort model among others [63]. Those indicators are often used in accordance to each country legislation [6466] to define their climatic zoning. There is no evidence in the literature reviewed in this paper on the overall impact in thermal comfort by the adoption of climatic zoning and corresponding building recommendations. The quantification of such impact is in fact cumbersome, particularly in cases where large data sets of measured data or simulation for the entire building stock are not available.

4 Methodologies and variables for climatic zoning for building energy efficiency programs 4.1 Variable, technique and/ or criterion used in the climatic zoning 
The review methodologies adopted by 54 countries for climate zoning reveal a large variability in approaches. This variability can be seen in Table 1, which shows a list of climatic variables, techniques for energy assessment and other criteria used by countries in their climatic zoning methodology. A total of 19 different variables, techniques and criteria are used, some more frequently than others but none used unanimously by the 54 countries analysed. In fact, the identification of so many approaches highlights the lack of consensus regarding the most suitable technique for climate zoning for building energy efficiency programs, stressing the need for further research in this field.

For clarity, these variables, techniques and criteria were classified in Table 1 in three groups: (a) climatic variables, (b) techniques for energy assessment and climate data processing and (c) other parameters. Figure 9 shows the frequency of use of each of them, which shows a clear prevalence of air temperature as a key variable in the definition of climatic zones. The frequency data of Figure 9 is further discussed in the following sub-sections, which discuss in detail the different approaches listed in Figure 9, addressing their strengths and weaknesses.

\subsection{Climatic variables}

Each climatic variable is expected to have a specific role in climate zoning methodologies for building energy efficiency programs, as each one of them contributes in different ways to variations of thermal loads, energy use of HVAC systems, lighting and energy production from solar and wind-based renewable systems $[67,68]$. However, quantifying the impact of climatic variables on energy usage of buildings is quite complex as these variables interact with several building and HVAC properties in the building energy balance $[55,69]$.

This study identified six climatic variables that were directly used in climatic zoning for building energy efficiency programs (Figure 9a), i.e. these variables were used as stand-alone entities being analysed in terms of frequency of occurrence, maximum and minimum values. Figure 9a does not include cases where variables are used indirectly, as input for building energy assessment, data segmentation techniques and other approaches listed in Figures $9 \mathrm{~b}$ and $9 \mathrm{c}$. The use of raw climatic data in climatic zoning has many advantages and it is rather straightforward, as most locations have large amounts of climatic data available for long time spans.

From the six climatic variables, temperature is by far the most used, being present in $56 \%$ of cases. The prevalence of temperature as a key climatic zoning parameter was expected, as it is usually seen as a major indicator of energy demand of HVAC systems. Energy demand of HVAC has a non-linear relationship with temperature, which is reasonably simple and predictable in cold climate but is erratic in warm countries due to the influence of other variables on cooling energy demand such as humidity, solar radiation, and wind [70]. Finland is a good example of a country with a cold climate using temperature as the primary input in its climatic zoning [49]. Figure 10a shows Finland climatic zoning, where outside design temperature is strongly correlated with latitude variations (which are also correlated to solar radiation intensity). In 
the Finish climatic zoning methodology, temperature was successfully used as it can be understood as a proxy of other climatic variables (e.g. solar radiation) which play important roles in building heating energy consumption. Ecuador is an example of country with a warm climate where temperature is the sole input for climatic zoning Figure 10b shows that climatic zoning of Equator takes advantage of the strong correlation between altitude and temperature in the Andes. Altitude is also strongly correlated to other climatic variables (e.g. cloudiness and solar radiation), but temperature and altitude cannot capture variations in rainfall and humidity between the Pacific Ocean side (west of the Andes) and the Amazon forest side (east of the Andes) (see rainfall intensity in Figure 10c). In this case, the sole use of temperature leads to an oversimplification of the climate zoning, ignoring the role of important elements for building energy performance, such as latent loads of HVAC, evaporative cooling solutions, thermal amplitude and its implications in HVAC controls and night ventilation solutions.

Relative humidity [71] or water vapor pressure, which are correlated indicators, is used as a complementary zoning parameter in $17 \%$ of the cases of this study. Those parameters are also related to rainfall intensity which appears in $10 \%$ of the cases, included in the ASHRAE method [24] applied to the USA, Puerto Rico and México. The ASHRAE method is also included in the International Energy Conservation Code [36], which covers more than 3012 locations outside the United States and Canada. These variables were used to complement climatic zoning methodologies based on temperature in order to cover a wide range of correlated important elements for cooling and heating energy consumption in buildings.

Solar radiation [72] is present in $16 \%$ of the cases. In hot climates, this variable is important because it is usually the main source of heat gains contributing to rising indoor temperatures. In cold climates, solar radiation can reduce buildings' heating energy consumption; however, it may also cause overheating during the summer. Solar radiation is also important for solar based renewable systems, which are issues of concern in some building energy efficiency programs [73]. Solar radiation is used, for example in the climatic zoning proposed for Net Zero energy buildings in Brazil, where solar radiation is used in combination with other variables and techniques to estimate renewable systems potential [74].

Wind velocity and direction are important parameters for buildings' thermal performance, particularly in poorly insulated buildings and buildings with natural ventilation for cooling purposes. Data availability and complexity of wind patterns usually reduce the usage of these data in climatic zoning methodologies. At the macro scale, wind modifies the temperature of the region according to movement of large air masses, an effect that is already captured by air temperature. At the building scale, wind affects building infiltration, ventilation, convective heat and mass transfer and people's perception of comfort. Wind is present in $9 \%$ of the cases of this study; among them Madagascar is an example where zones are defined according to the wind speed and frequency (in combination with other climatic variables) [56]. 
Another important variable related to building energy demand is thermal amplitude, which is present in $6 \%$ of the cases. Thermal amplitude is the numerical difference between maximum and minimum temperatures observed in a given location over a specified time period. This variable is considered a key indicator for selecting bioclimatic design responses to keep indoor air temperature within comfortable ranges [75]. Thermal amplitude is strongly correlated with other variables such as relative humidity and the presence of bodies of water in the region. Argentinean climatic zoning [15] is an example of classifications taking into account this variable as a complementary parameter for classification.

This section addressed the role of six climatic variables in climatic zoning methodologies. The next sections are dedicated to techniques for energy assessment, climate data processing and other parameters listed in Table 1.

\subsection{Degree days}

The degree day approach is one of the most commonly used techniques for climate zoning, being used in $38 \%$ of the cases of this study. Degree days are calculated from the summation of the differences between the outdoor temperature and a base temperature over a specified time period. The base temperature is arbitrary, but it is usually defined as the external temperature where HVAC systems do not need to work to maintain comfort conditions inside the building. Degree days capture variations of outdoor temperature in terms of amplitude and frequency with respect to a reference temperature [76]. This approach had its origin in agricultural research and was transferred to the building energy field in the decade of 1930 [77]. The degree days approach can be used in steady-state calculations to estimate energy demand for cooling and heating systems based on the U-value of construction materials.

Degree days have the advantage of being simple and having a reduced number of input variables, which diminishes errors in the climatic zoning. Due to its simplicity, degree days have been widely used in the building energy field and they are a reliable indicator of building energy consumption in cold climates [69]. Despite its advantages, this technique provides a partial understanding of the influence of climatic variables in buildings as it disregards the impact of solar radiation, wind speed and humidity. These additional variables are important in hot humid climates, where solar gains and latent loads have a large influence on building energy performance. Therefore, in most cases the degree days approach has been used for climatic zoning in combination with other climatic variables, such as in the ASHRAE method [24] mentioned above.

\subsection{Building energy simulation}

Building energy simulation has been used in $8 \%$ of cases analyzed in this study. Simulation programs are considered the most accurate method to predict thermal building performance, providing a better understanding of the consequences of design decisions [78]. They emerged in the decade of 1960 and since then have continuously evolved and matured [7880]. Nowadays, their accuracy and interoperability with other programs allows the performance assessment of a broad range of architectural and engineering solutions, which makes possible the establishment of detailed predictive-based and 
performance-based requirements for building energy efficiency programs $[81,82]$. However there are some constraints in the use of building simulation, such as the need to predefine a design hypothesis which varies according to architectural typology, HVAC, occupational patterns and building control. In addition, there is a need for detailed climatic data [67,83], which are not always available for the regions of interest. Such complexity makes climatic zoning by building energy simulation not always feasible and also prone to errors.

Building energy simulation has shown great potential when applied to climate zoning, particularly through parametric analysis as, for example, in the case of Morocco [20]. In Morocco, thermal regulations and climatic zoning were defined with the aid of simulation, indicating prescriptive-based and performance-based requirements for residential and commercial buildings. Cooling and heating energy demand was used as climatic zoning indicator, as cities were grouped in zones according to different combinations of these two parameters (Figure11). The study was performed with TRNSYS software [84].

\subsection{Cluster analysis}

Cluster analysis is the general name for a variety of techniques for data classification and segmentation, present in $6 \%$ of the cases in this study. For climatic zoning purposes, clustering is either applied alone or using factorial analyses to preprocess data and reduce the number of variables for clustering [85]. Cluster analysis has been applied in atmospheric research to find homogeneous climate zones based on meteorological parameters. It is considered a multivariate pattern recognition technique that helps to investigate climate data under various aspects simultaneously for a wide range of research questions [86]. This method emerged as a major analysis technique in the decades of 1960 and 1970 [87].

The use of cluster analysis in climatic zoning has two main advantages. Firstly, cluster analysis makes possible the use of large range of climatic and geographical variables which may influence building energy performance, avoiding oversimplifications already described in most methods which are focused on a single or few variables. Secondly, and most importantly, cluster analysis can combine climatic variables with building properties (such as U-values) and energy performance (from simulations or smart meter data), providing an unique approach to define climatic zones based on relevant aspects for building performance (building properties and energy consumption). Judgment must be used in many stages of analysis cluster analysis, which provides the means for decision making and customization in the climatic zoning process [24]. France is an example of country which defined its climatic zones using a combination of clustering and factorial analyses [34], subsequently used in its thermal regulation [48].

\subsection{Givoni bioclimatic chart}

The Givoni bioclimatic chart [58] is a pre-design bioclimatic tool used in 5\% of the cases analysed in this study. This tool correlates passive design strategies with external air temperatures and relative humidity using a custom psychrometric 
chart. This bioclimatic chart was developed by Givoni [58] based on Olgyay's work [88] and over the years it has been the subject of several improvements and adaptations to different contexts [14].

The main advantages of the Givoni bioclimatic chart are its easiness of application and the reduced number of input variables, which reduce errors in the zoning process. However, as with other approaches already described in this paper, the Givoni bioclimatic chart disregards some climatic variables that influence thermal behaviour of buildings, such as solar radiation and wind exposure. In fact, some studies raised questions about the generalized applicability of this tool [89] and pointed out its limitation in the face of recent developments in adaptive thermal comfort [90]. An example of Givoni bioclimatic chart application for climatic zoning definition can be found in Brazil [14], where this tool was used with Mahoney tables to define climatic zones and draw recommendations of passive design strategies for social housing (Figure 12).

\subsection{Mahoney tables}

Mahoney tables are used in a few cases analysed in this study (3\%). This method was developed by Carl Mahoney, Martin Evans and Otto Königsberger [91] and provides passive design recommendations in early design stages based on monthly climatic data. The main advantages of Mahoney tables are the simplicity and low input requirements. Predominant climatic features are identified using Mahoney tables, and consequently, the corresponding passive design solution. However, it is not meant to support detailed prescriptive-based or performance-based recommendations. In addition to this, comfort limits established in this method are mostly aimed at tropical climate, being less accurate in colder climates [92]. For climatic zoning purposes, Mahoney tables have been applied only in Brazil [14] and Nigeria [93].

\subsection{Other parameters}

There is a third group of parameters composed of a diverse set of indicators not directly related to the analysis of climate data or building performance. These parameters are related to geographical, urban, architectural and administrative characteristics of a location and they are present in $54 \%$ of the climatic zoning analysed in this study. Among them, altitude is the most used indicator. It is considered as a complementary parameter of climatic zoning in $22 \%$ of the cases analyzed in this study. This geographical characteristic has a well-known correlation with temperature variation [94] as shown in the example of Ecuador (Figure 10b). Altitude is particularly useful and often used to interpolate climatic data when there are not enough weather stations to delineate a high resolution map.

Division for administrative purposes is used in $16 \%$ of the countries. This criterion facilitates the implementation of building energy efficiency programs; however, it decouples climatic zoning from climatic data. By facilitating the implementation, this approach puts at risk the applicability of climatic zoning as zones may have no meaning in terms of climate and building energy performance. 
Seasonality is used in $16 \%$ of the cases of this study. Defining separate climatic zonings for summer and winter adds complexity to the climatic zoning process, but it can enhance the definition of building requirements targeting separately cooling or heating needs. It also demonstrates the understanding that climatic data vary in space (hence the need for climatic zones), but this variation in space may assume different boundaries over the year (hence the need for climatic zones for each season). Seasonality is addressed differently from one country to another. In Portugal [95], for example, there are separate maps for winter and summer thermal requirements (Figure 13). In Spain [96] and France [48], there is a main zone division and specific subdivisions targeting thermal requirements for summer and winter.

There is a reduced number of countries using the remaining parameters listed in Table 1, such as vernacular architecture [97], Köppen climate classification [98], thermal inversion [99], size of urban agglomeration [34] and thermal comfort index [15]. These parameters will not be further analyzed here, as they were adopted by a single country and this paper is focused on general trends in climatic zoning for building energy programs.

\subsection{Combination of methodologies}

The previous sections described a variety of techniques used in the climatic zoning of the many countries covered by this review. This section briefly discusses the trends in the combination of these techniques adopted by different countries. Figure 14 shows the frequency of occurrence for the number of techniques used simultaneously by different countries in their climatic zoning methodology. Around one out of three cases $(31 \%)$ relies on a single technique to define climatic zoning. Temperature, degree days and simulation are the most used techniques (or variables) in these cases. In $31 \%$ of the cases, two techniques were combined, usually using temperature or degree days in combination with some indicator of humidity level (e.g. relative humidity, vapor pressure, rainfall).

Four out of five cases analysed in this study (78\%) used up to three techniques or variables to define climatic zoning for building energy efficiency programs. Seasonality, altitude and solar radiation are sometimes, but not often, combined with temperature, degree days, humidity or administrative division in these cases. These results indicate that very few aspects are actually taken into account in the current climatic zoning methodologies. A possible explanation for this result is the difficulty of handling large datasets, with several variables sparsely distributed in space. The recent popularization of Geographic Information Systems (GIS) greatly facilitate the necessary data manipulation for climatic zoning. Nevertheless GIS does not solve by itself the methodological challenge of extracting meaningful zones from several climatic variables. In face of this challenge, most countries appear to create an initial version of the climatic zoning using a single variables and adopting bandwidths of arbitrary size. This initial version is then refined by sub-dividing zones based on a second or third variable, such as humidity and/or solar radiation. This straightforward approach can certainly produce useful results, 
as most countries are currently adopting climatic zoning based on it. Nevertheless it has major limitations which were highlighted in this review paper.

\section{Conclusions}

The following conclusions can be drawn from the large amount of data collected and analysed in this paper:

- Approximately $70 \%$ of the world land surface is subject to climate zoning for building energy efficiency programs, representing $71 \%$ of world population and $85 \%$ of the total primary energy consumption.

- A significant number of countries revised or introduced climatic zoning in the last 15 years.

- The number of zones has no direct relation with the country area, varying in area from approximately $10^{3} \mathrm{~km}^{2}$ to approximately $1.810^{6} \mathrm{~km}^{2}$.

- The number of zones does not seem to be related to climatic variations, but it is most probably driven by the expected simplicity of the final climatic zoning (with up 4to 8 zones being the standard practice).

- This review could not identify any scientific method widely accepted to deal with the trade-offs between complexity and accuracy in the definition of the number of climatic zones necessary in a country for a given purpose (e.g. regulation and design guidelines).

- Climate zones for building energy efficiency programs are developed with a variety of goals, but most of them $(86 \%)$ are designed to support performance-based and/or prescriptive-based requirements for building regulation.

- The most used variables, techniques and parameters for climate zoning are: temperature, degree days, altitude and relative humidity.

- Four out of five cases analysed in this study (78\%) used up to three variables/techniques/parameters to define climatic zoning for building energy efficiency programs. This simplicity comes at the cost of ignoring several aspects of climate and building energy performance.

- There is an increase over the years in the use of building performance simulation to assist in the definition of climate zones, moving from a weather-based approach to a performance-based approach. There is no established framework for the use of simulation in the definition of climate zones for building energy programs.

- From the techniques identified in this review, only the combination of building performance simulation and cluster analysis seems to provide robust tools to tackle the complex relations between climate and building energy performance. These tools do not necessarily lead to improved climatic zoning, but they provide the means to explore scenarios and support evidence-based decision making in energy policy.

- The lack of consensus in several aspects of climate zoning in different countries indicates the need for further research in this area. 


\section{Acknowledgement}

This study was partially supported by the Brazilian National Council for the Improvement of Higher Education (CAPES) [grant number 15283127] and the Brazilian National Council for Scientific and Technological Development (CNPq) [grant number 311641/2013-0].

\section{References}

[1] P. Vitruvius, M.H. Morgan, The Ten Books on Architecture, Cambridge : Harvard University Press, London, 1914.

[2] Z. (John) Zhai, J.M. Previtali, Ancient vernacular architecture: characteristics categorization and energy performance evaluation, Energy and Buildings. 42 (2010) 357-365.

[3] S. Bodach, W. Lang, J. Hamhaber, Climate responsive building design strategies of vernacular architecture in Nepal, Energy and Buildings. 81 (2014) 227-242.

[4] J. Borel, Application du règlement de la construction en Algérie. Définition des zones climatiques. Cahier du CSTB No 57, (1962).

[5] M. Thyholt, T.D. Pettersen, T. Haavik, B.J. Wachenfeldt, TASK 37 Advanced housing renovation by solar and conservation. Energy analysis of the norwegian dwelling stock, 2009.

[6] German Institute for Standardization (DIN), DIN 4108:1960-Thermal insulation in buildings (in german), 1960.

[7] RSAS, BABS-Byggnadsstyrelsen's Instructions to the Building Law (Original: Anvisningar till byggnadsstadgan BABS 1960-in swedish), Stockholm, Sweden, 1960.

[8] CSIRO building construction and engineering for the australian green house office, Feasibility study - A national approach to energy efficiency measures for houses, Camberra, 2000.

[9] United Nations Development Programme/Global Environment Facility and Ministry of Public Works and Transport/General Directorate of Urban Planning, Climatic zoning for buildings in Lebanon. Project capacity building for the adoption and application of thermal standards for buildings, 2005.

[10] International Energy Agency/United Nations Development Programme, Modernising building energy codes to secure our global energy future: Policy pathway, New York, 2013.

[11] J. Jacobeit, Classifications in climate research, Physics and Chemistry of the Earth. 35 (2010) 411-421.

[12] N. Sánchez-Santillán, R.L. Garduño, Sistemas de clasificación climática, Contacto S. 68 (2008) 5-10.

[13] M. Kottek, J. Grieser, C. Beck, B. Rudolf, F. Rubel, World map of the Köppen-Geiger climate classification updated, Meteorologische Zeitschrift. 15 (2006) 259-263.

[14] M. Roriz, E. Ghisi, R. Lamberts, Bioclimatic zoning of Brazil: a proposal based on the Givoni and Mahoney methods, in: The 16th International Conference on Passive and Low Energy Architecture, Brisbane, Australia, 1999.

[15] Instituto Argentino de Normalización y certificación, Norma IRAM 11603-1996: acondicionamiento térmico de edificios: clasificación bioambiental de la Republica Argentina, Buenos Aires, Argentina, 2011.

[16] Bureau of Energy Efficiency, Energy conservation building code-India, 2006.

[17] A. Youssef, Climate zone map (CZM) tool for building energy compliance in Saudi Arabia, in: 2016 ASHRAE Winter Conference, Orlando, FL, USA, 2016.

[18] Australian Building Codes Board, International survey of building energy codes, Canberra, 2000.

[19] J.M. Evans, Zonificación bioambiental en Latinoamérica para una arquitectura sustentable, Avances En Energías Renovables Y Medio Ambiente. 8 (2004) 163-168.

[20] Agence Nationale pour le Développement des Énergies Renouvelables et de l’Efficacité Énergétique Maroc, Les éléments techniques du projet de la réglementation thermique du bâtiment au Maroc, Rabat, 2011.

[21] California Energy Commission, Building energy efficiency standards for residential and nonresidential buildings, 2013.

[22] Building Research Establishment, SAP 2012 -The Government's standard assessment procedure for energy rating of dwellings, (2014).

[23] M. Webs, T. Deutschländer, J. Christoffer, Testreferenzjahre von Deutschland für mittlere und extreme witterungsverhältnisse TRY, 2004. 
[24] R.S. Briggs, R.G. Lucas, Z.T. Taylor, Climate classification for building energy codes and standards, in: ASHRAE Transactions, Atlanta, USA, 2003.

[25] Collectif Effinergie, Règles techniques applicables aux bâtiments faisant l'objet d'un e demande de label Bepos-Effinergie, (2015) 1-6.

[26] W. Bustamante, Y. Rozas, R. Cepeda, F. Encinas, P. Martinez, Guía de diseño para la eficiencia energética en la vivienda social, MIMVU CNE, Santiago de Chile, Chile, 2009.

[27] E.G. Dascalaki, C.A. Balaras, A.G. Gaglia, K.G. Droutsa, S. Kontoyiannidis, Energy performance of buildings - EPBD in Greece, Energy Policy. 45 (2012) 469-477.

[28] Ministerio de ambiente y desarrollo, Criterios ambientales para el diseño y construcción de vivienda urbana, Bogotá, Colombia, 2012.

[29] S. Bodach, Developing bioclimatic zones and passive solar design strategies for Nepal, in: 30th International Conference on Passive and Low Energy Architecture, Ahmedabad, India, 2014.

[30] Ministerio de Desarrollo Urbano y Vivienda, Norma Ecuatoriana de la Construcción (NEC-11)/Capítulo 13-Eficiencia energética en la construcción en Ecuador, Ecuador, 2011.

[31] S. Pusat, I. Ekmekci, A study on degree-day regions of Turkey, Energy Efficiency. 9 (2016) 525-532.

[32] U.S. Energy Information Administration, International Energy Statistics, (2012). http://www.eia.gov/cfapps/ipdbproject/IEDIndex3.cfm?tid=44\&pid=44\&aid=2 (accessed January 10, 2016).

[33] World Bank, World Development Indicators: Size of the economy, 2014. (2014). http://wdi.worldbank.org/table/1.1 (accessed February 18, 2016).

[34] J. Arenes, P. Elias, Classification climatique des communes françaises, CSTB, Paris, 2003.

[35] United States Department of Energy, Status of state energy code adoption, (2015). https://www.energycodes.gov/status-stateenergy-code-adoption (accessed January 10, 2016).

[36] International Code Council, IECC-2012- International Energy Conservation Code, USA, 2012.

[37] ANSI/ASHRAE/IESNA, ANSI/ASHRAE/IES Standard 90.1-2010. Energy standard for buildings except low-rise residential buildings, 2010.

[38] California Energy Commission, California energy maps, (2016).

http://www.energy.ca.gov/maps/renewable/building_climate_zones.html (accessed April 4, 2016).

[39] Agence Nationale des Energies Renouvelables, Zonage climatique pour la Tunisie, 2004.

[40] D.W. Ware, P. Bozorgchami, Energy efficiency comparison-California's Building Energy Efficiency Standards and the IECC and ASHRAE standard 90.1, CEC, 2013.

[41] K. Bawaneh, M. Overcash, J. Twomey, Climate zones and the influence on industrial nonprocess energy consumption, Journal of Renewable and Sustainable Energy. 3 (2011) 0-8.

[42] T.A.L. Martins, L.S. Bittencourt, C.M.L.B. Krause, Contribuição ao zoneamento bioclimático brasileiro: reflexões sobre o semiárido nordestino, Ambiente Construído. 12 (2012) 59-75.

[43] M. Carpio, J. Jódar, M.L. Rodíguez, M. Zamorano, A proposed method based on approximation and interpolation for determining climatic zones and its effect on energy demand and $\mathrm{CO} 2$ emissions from buildings, Energy and Buildings. 87 (2015) 253-264.

[44] A.S. Pawar, M. Mukherjee, R. Shankar, Thermal comfort design zone delineation for India using GIS, Building and Environment. 87 (2015) 193-206.

[45] Associação Brasileira de Normas Técnicas, NBR 15575-1 2013 Edificações habitacionais-Desempenho, Rio do Janeiro, Brazil, 2013.

[46] G.R. Netto, J.D. Czajkowski, Comparación entre las normas de desempeño térmico edilício de Argentina y Brasil, Ambiente Construído. 16 (2016) 105-122.

[47] F. Liu, A.S. Meyer, J.F. Hogan, Mainstreaming building energy efficiency codes in developing countries. Global experiences and lessons from early adopters, WB, Washington, D.C., 2010.

[48] Ministère de l'environnement de l'énergie et de la mer, RT-2012, (2012). http://www.rt-batiment.fr/batimentsneufs/reglementation-thermique-2012/donnees-meteorologiques.html (accessed February 15, 2016).

[49] Ministry of the Environment- Department of the Built Environment, National building code of Finland, Part D5, Calculation of energy consumption and heating power of buildings, (2007) 246. 
[50] M. Evans, M. Halverson, A. Delgado, S. Yu, Building energy code compliance in developing countries: the potential role of outcomes-based codes in India, in: 2014 ACEEE Summer Study on Energy Efficiency in Buildings, Pacific Grove, CA, 2014: pp. 61-74.

[51] C.C.S. Lau, J.C. Lam, L. Yang, Climate classification and passive solar design implications in China, Energy Conversion and Management. 48 (2007) 2006-2015.

[52] B. Givoni, Passive cooling of buildings by natural energies, Energy and Buildings. 2 (1979) 279-285.

[53] S. Stevanović, Optimization of passive solar design strategies: A review, Renewable and Sustainable Energy Reviews. 25 (2013) 177-196.

[54] J. Khedari, A. Sangprajak, J. Hirunlabh, Thailand climatic zones, Renewable Energy. 25 (2002) 267-280.

[55] J.A. Clarke, Energy simulation in building design, Taylor \& Francis group, 2001.

[56] O. Rakoto-Joseph, F. Garde, M. David, L. Adelard, Z. a. Randriamanantany, Development of climatic zones and passive solar design in Madagascar, Energy Conversion and Management. 50 (2009) 1004-1010.

[57] M.K. Singh, S. Mahapatra, S.K. Atreya, Development of bio-climatic zones in north-east India, Energy and Buildings. 39 (2007) 1250-1257.

[58] B. Givoni, Comfort, climate analysis and building design guidelines, Energy and Buildings. 18 (1992) 11-23.

[59] M.K. Singh, S. Mahapatra, J. Teller, Development of thermal comfort models for various climatic zones of North-East India, Sustainable Cities and Society. 14 (2015) 133-145.

[60] R.J. De Dear, T. Akimoto, E.A. Arens, G. Brager, C. Candido, K.W.D. Cheong, et al., Progress in thermal comfort research over the last twenty years, Indoor Air. 23 (2013) 442-461.

[61] S. Manu, Y. Shukla, R. Rawal, L.E. Thomas, R. de Dear, Field studies of thermal comfort across multiple climate zones for the subcontinent: India Model for Adaptive Comfort (IMAC), Building and Environment. 98 (2016) 55-70.

[62] R. De Vecchi, M.J. Sorgato, C. Cândido, R. Lamberts, Application of the adaptive model proposed by ASHRAE 55 in the Brazilian climate context : raising some issues, 8th Windsor Conference. 15251 (2014) 13.

[63] A.S. Silva, E. Ghisi, R. Lamberts, Performance evaluation of long-term thermal comfort indices in building simulation according to ASHRAE Standard 55, Building and Environment. 102 (2016) 95-115.

[64] BEAR-iD NOBATEK, European climate zones and bio-climatic design requirements Project report, 2016.

[65] ANSI/ASHRAE, Standard 55-2013:Thermal Environmental Conditions for Human Occupancy, 2013.

[66] M. Taleghani, M. Tenpierik, S. Kurvers, A. Van Den Dobbelsteen, A review into thermal comfort in buildings, Renewable and Sustainable Energy Reviews. 26 (2013) 201-215.

[67] J.L.M. (Jan) Hensen, Simulation of building energy and indoor environmental quality - Some weather data Issues, in: The International Workshop on Climate Data and Their Applications in Engineering, Prague, Czech Republic, 1999.

[68] T. Hong, W. Chang, H. Lin, A fresh look at weather impact on peak electricity demand and energy use of buildings using $30-$ year actual weather data, Berkeley National Laboratory, 2013.

[69] A. Makhmalbaf, V. Srivastava, N. Wang, Simulation-based weather normalization approach to study the impact of weather on energy use of buildings in the U.S., in: 13th Conference of International Building Performance Simulation Association, Le Bourget Du Lac, France, 2013: pp. 1436-1444.

[70] M. Bessec, J. Fouquau, The non-linear link between electricity consumption and temperature in Europe: A threshold panel approach, Energy Economics. 30 (2008) 2705-2721.

[71] F. Ge, X. Guo, H. Liu, J. Wang, C. Lu, Energy performance of air cooling systems considering indoor temperature and relative humidity in different climate zones in China, Energy and Buildings. 64 (2013) 145-153.

[72] A. Prada, G. Pernigotto, P. Baggio, A. Gasparella, Effect of solar radiation model on the predicted energy performance of buildings, in: 3rd International Hight Performance Buildings Conference at Purdue, Indianápolis, USA, 2014.

[73] D. D'Agostino, Assessment of the progress towards the establishment of definitions of Nearly Zero Energy Buildings (nZEBs) in European Member States, Journal of Building Engineering. 1 (2015) 20-32.

[74] L. Domingo, D. Kalz, A. Dinkel, L. Lomardo, V. Silva, Definição de uma classificação climática para o estudo de edificações com balanço anual zero de energia no Brasil, in: XV Encontro Nacional de Tecnologia Do Ambiente Construido, Maceió, Brazil, 2014: pp. 213-222.

[75] J.M. Evans, The Comfort Triangles: A new tool for bioclimatic design, Delft University, 2007.

[76] The Chartered Institution of Building Services Engineers, Degree-days: theory and application, Ken Butche, CIBSE, London, 
2006.

[77] M. De Rosa, V. Bianco, F. Scarpa, L.A. Tagliafico, Historical trends and current state of heating and cooling degree days in Italy, Energy Conversion and Management. 90 (2015) 323-335.

[78] A. Malkawi, G. Augenbroe, Advanced building simulation, Spon Press, New York, London, 2003.

[79] J.. A. Clarke, Building energy simulation: The state-of-the-art, Solar \& Wind Technology. 6 (1989) 345-355.

[80] D.B. Crawley, J.W. Hand, M. Kummert, B.T. Griffith, Contrasting the capabilities of building energy performance simulation programs, Building and Environment. 43 (2008) 661-673.

[81] D.B. Crawley, Building performance simulation: a tool for policymaking, University of Strathclyde, 2008.

[82] S. Bodach, W. Lang, Design guidelines for energy-efficient hotels in Nepal, International Journal of Sustainable Built Environment. 5 (2016) 411-434.

[83] D.B. Crawley, Which weather data should you use for energy simulations of commercial buildings?, in: ASHRAE (Ed.), ASHRAE Transactions, Atlanta, 1998: pp. 498-515.

[84] S.A. et al Klein, TRNSYS 17: A Transient System Simulation Program, Solar Energy Laboratory, University of Wisconsin, Madison, USA, 2010.

[85] L. Lebart, A. Morineau, M. Piron, Statistique exploratoire multidimensionnelle, Dunod, Paris, 1995.

[86] T. Nocke, H. Schumann, U. Böhm, Methods for the visualization of clustered climate data, Computational Statistics. 19 (2004) 75-94.

[87] H.-H. Bock, Origins and extensions of the k-means algorithm in cluster analysis, Journal Electronique d'Histoire Des Probabilités et de La Statistique. 4 (2008) 1-18.

[88] V. Olgyay, Design with climate: bioclimatic approach to architectural regionalism, 1963.

[89] K.J. Lomas, D. Fiala, M.J. Cook, P.C. Cropper, Building bioclimatic charts for non-domestic buildings and passive downdraught evaporative cooling, Building and Environment. 39 (2004) 661-676.

[90] J.F. Nicol, M.A. Humphreys, Adaptive thermal comfort and sustainable thermal standards for buildings, Energy and Buildings. 34 (2002) 563-572.

[91] O.H. Koenigsberger, C.T. Mahoney, M. Evans, Climate and house design, New York, 1971.

[92] B. Xia, Thermal comfort and the Mahoney tables in Shanghai building bioclimatic design, Advances in Information Sciences and Service Sciences. 5 (2013) 27-33.

[93] O.O. Ogunsote, B. Prucnal-Ogunsote, Defining climatic zones for architectural design in Nigeria : A systematic delineation, Journal of Environmental Technology. 1 (2002) 1-14.

[94] K. Wang, J. Sun, G. Cheng, H. Jiang, Effect of altitude and latitude on surface air temperature across the Qinghai-Tibet Plateau, Journal of Mountain Science. 8 (2011) 808-816.

[95] S. Camelo, C. Pina dos Santos, Á. Ramalho, C. Horta, H. Gonçalves, E. Maldonado, Regulamento das características do comportamento térmico dos edifícios manual de apoio à aplicação do RCCTE, Lisboa, Portugal, 2006.

[96] Ministerio de Fomento, Código técnico de la edificación - Sección HE 0 Limitación del consumo energético caracterización y cuantificación de la exigencia procedimiento de verificación demanda energética y condiciones operacionales, Spain, 2014.

[97] F. Campos Navarro, Arquitetura e clima na Bolívia : Uma proposta de zoneamento, Universidade Estadual de Campinas, 2007.

[98] D. Conradie, T. Kumirai, The creation of a South African climate map for the quantification of appropriate passive design responses, in: 4th CIB International Conference on Smart and Sustainable Built Environments, São Paulo, 2010.

[99] Instituto de la Construcción y Gerencia, Norma EM.110 Confort térmico y lumínico con eficiencia energética, Peru, 2014. 


\section{Figures}

\section{(Single column-fitting image)}

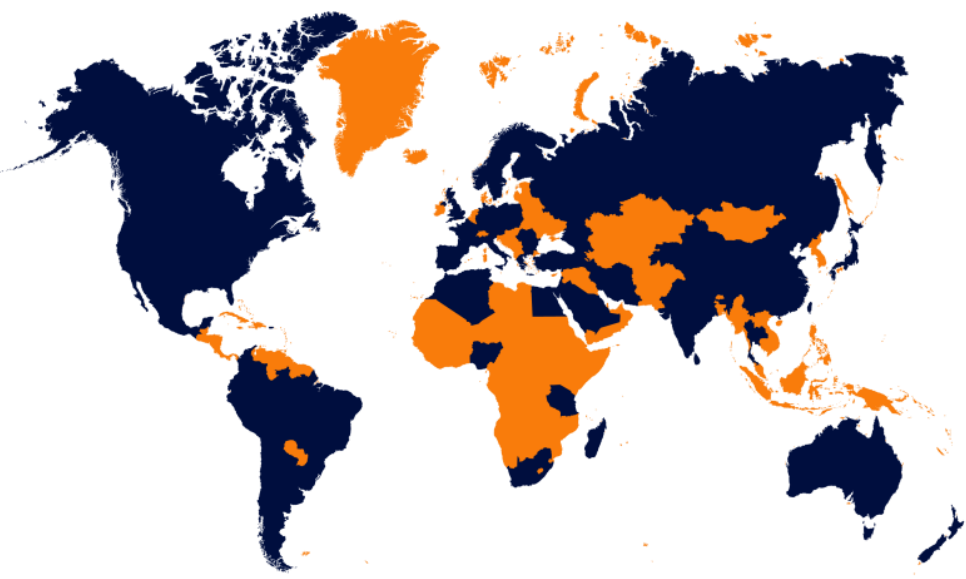

Countries having climatic zoning covered in this review Countries not covered in this review

Figure 1. Countries with climatic zoning covered in this review

(Single column-fitting image)

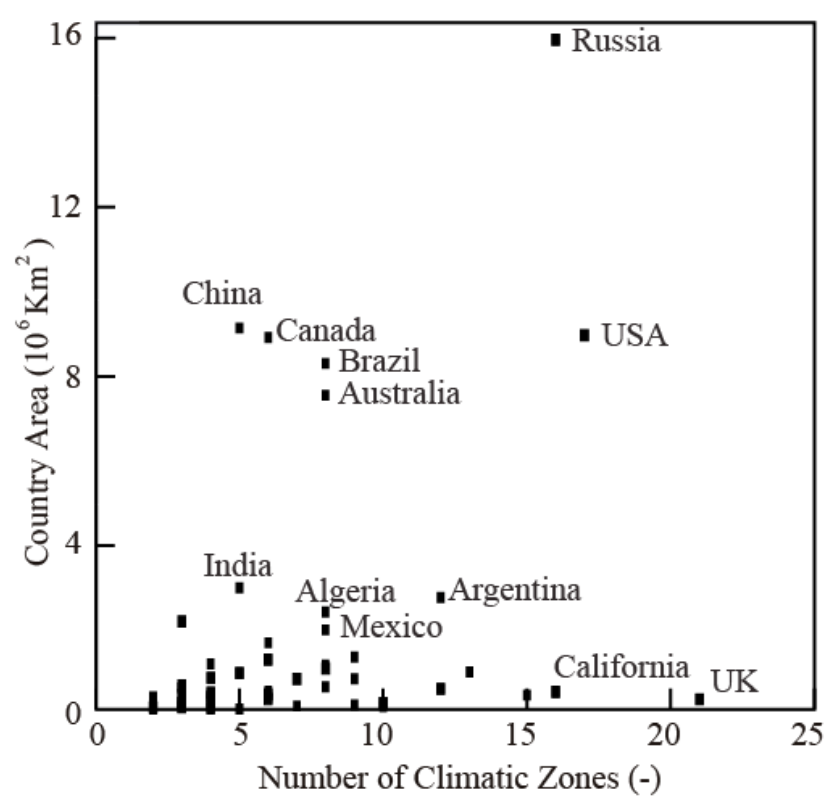

Figure 2: Correlation of country area and number of climatic zones 
a)

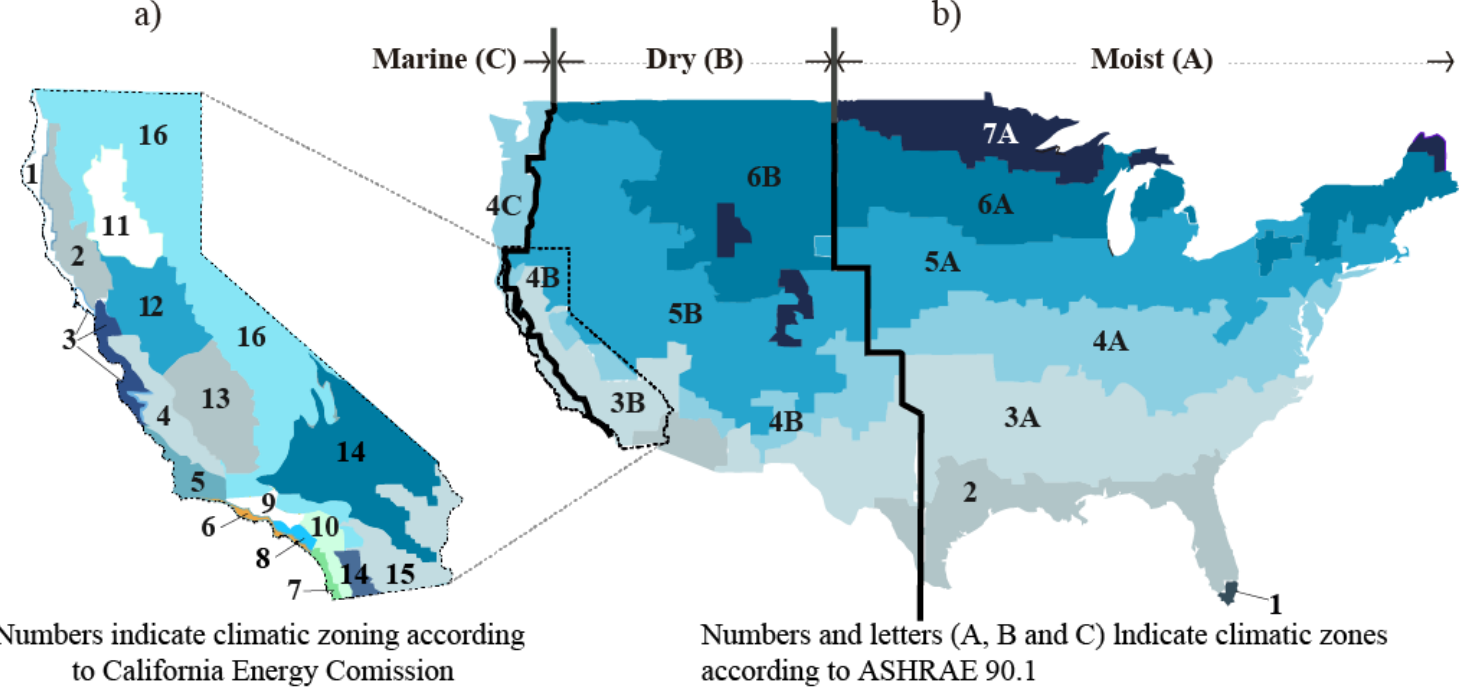

Figure 3: California State and USA climate zonings [21,37]

Single-column fitting image

a)

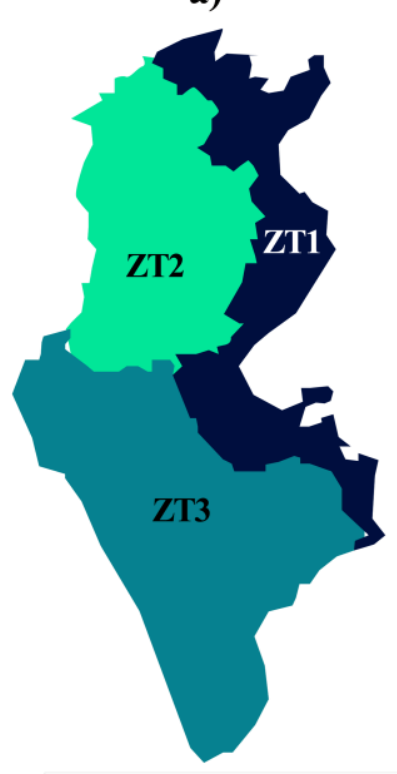

Climatic zones for thermal regulation

$$
\text { ZT1 }
$$$$
\text { ZT3 }
$$

b)

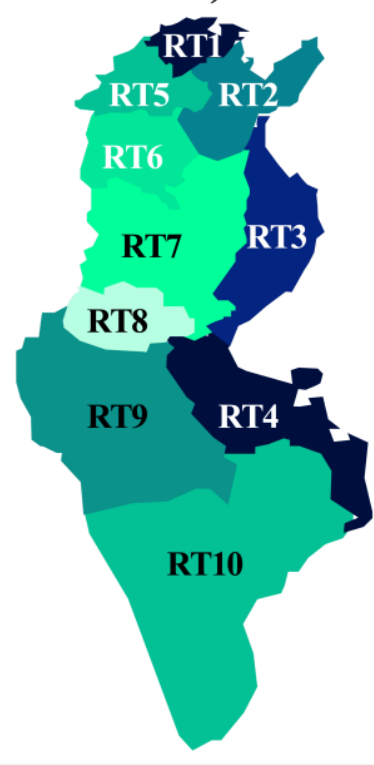

Climatic zones for building design guidelines

RT1+RT2+RT3+RT4

RT5+RT6+RT7

RT9+RT10

Figure 4: Tunisia climatic zoning-maps with different resolution for thermal regulation (a), for passive design guidelines (b) [39] 


\section{2-column fitting image}
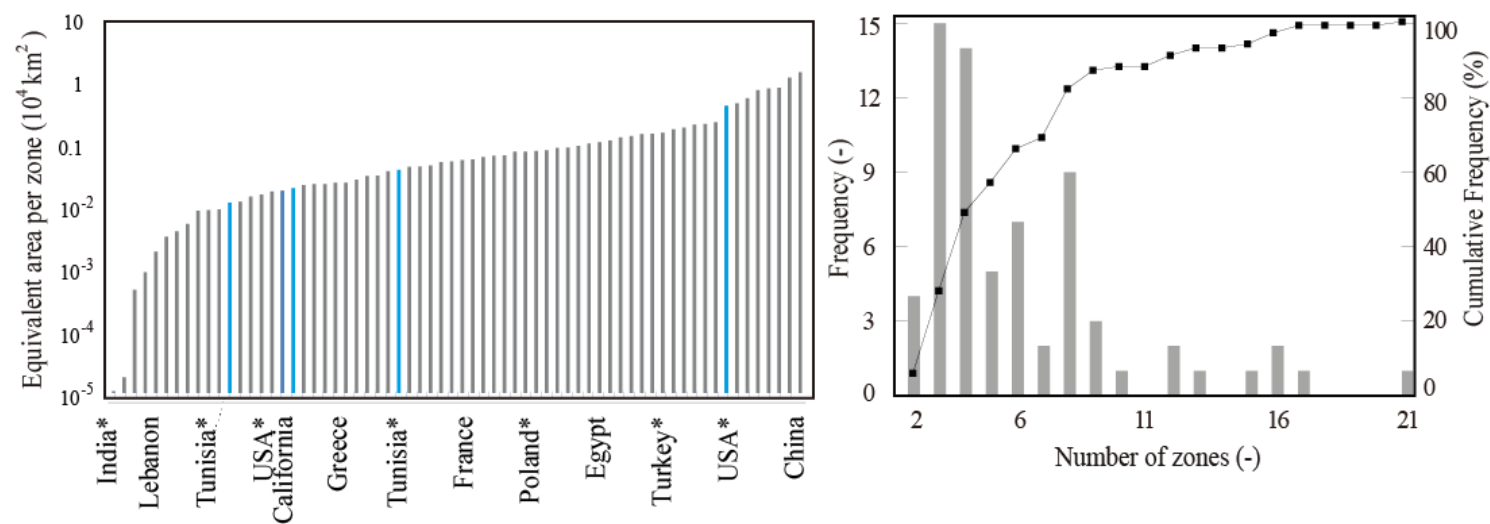

* Country having different climate zoning schemes

- Climatic zoning with different resolution for the same country

Figure 5: Average area per zone (a) and histogram of the number of zones used in different climatic zoning covered in this review (b)

\section{2-column fitting image}

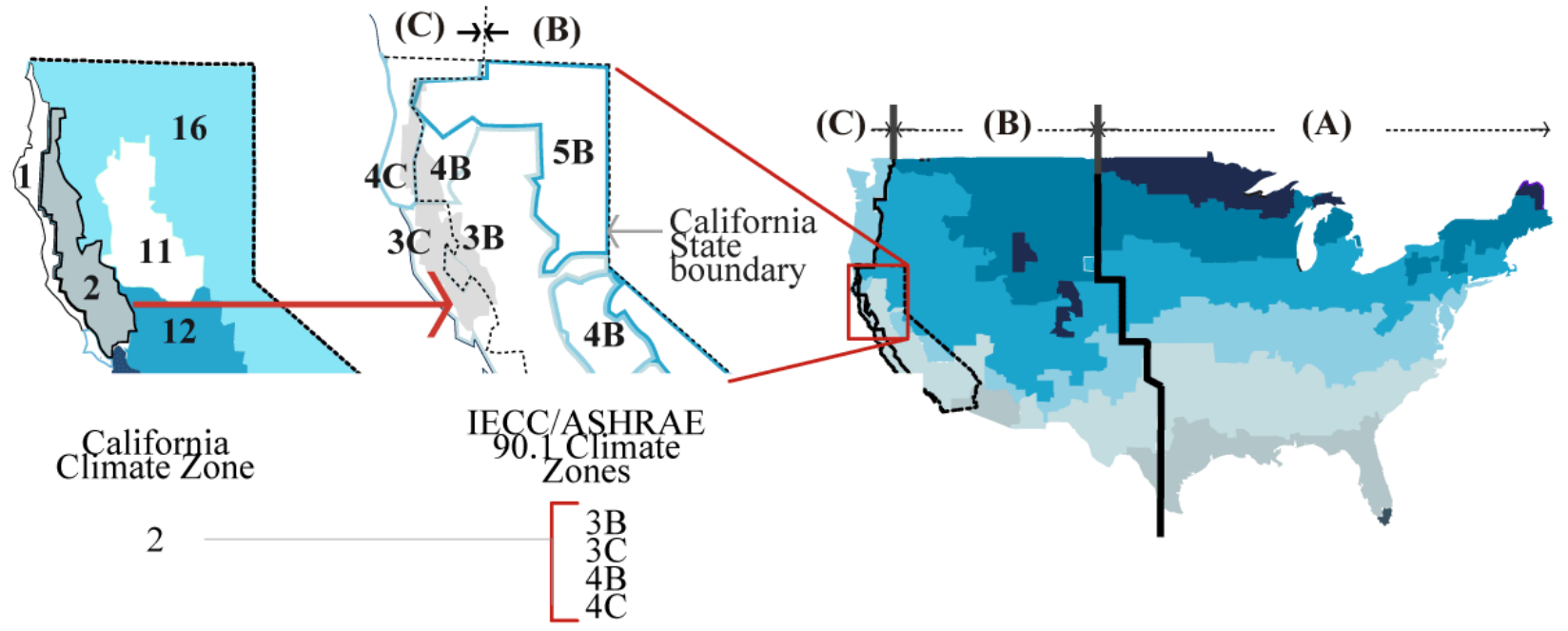

Figure 6: Different requirements for the same region of California [40] 


\section{Single-column fitting image}

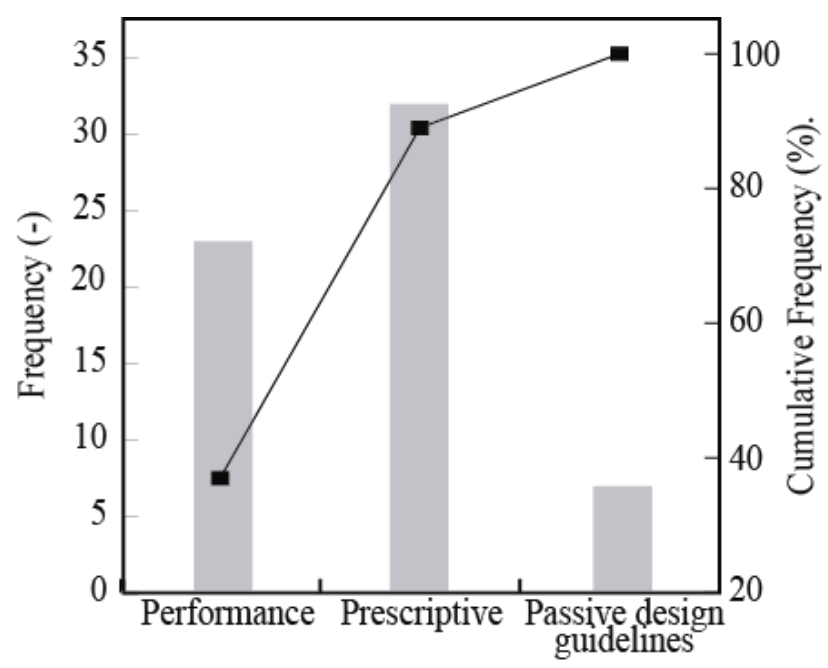

Figure 7: Frequency of climatic zoning according to their purpose

\section{2-column fitting image}

a)

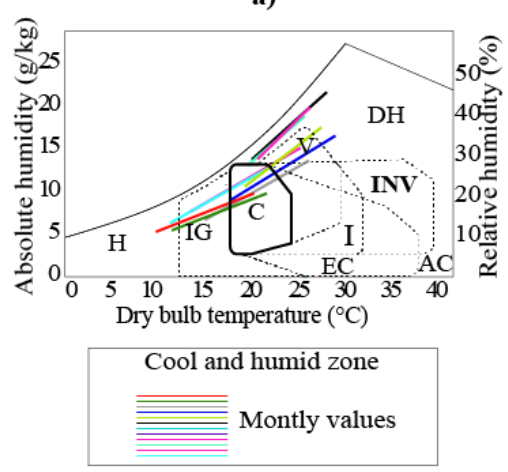

\section{C - Comfort}

AC - Cooling

DH - Dehumification

EC - Evaporative cooling

H- Heating

I - High Inertia

IG - Internal Gains

INV - High Inertia and Night Ventilation

V - Ventilation b)

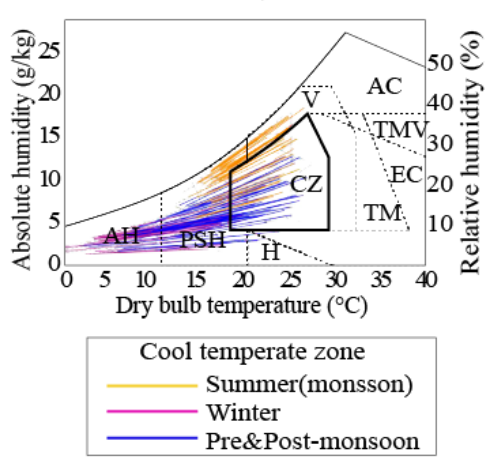

Strategies for thermal conditioning
CZ - Comfort
PSH - Passive solar heating
AH - Active heating
V - Ventilation
TM - Thermal mass
TMV - Thermal Mass with
night ventilation
EC- Evaporative cooling
AC-Cooling
H - Humidification

c)

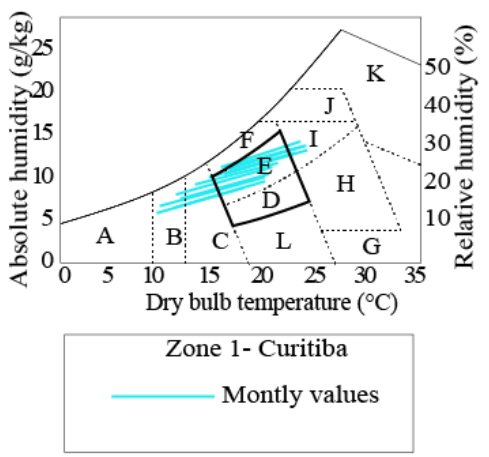
A- Artificial heating system
B + C - Solar heating
C - Thermal mass
D - Thermal comfort (low humidity)
E - Thermal comfort
F - Ventilation: air replacement
$\mathbf{G}+\mathbf{H}$ - Evaporative cooling
$\mathbf{H}+\mathbf{I}$ - Thermal mass for cooling
$\mathbf{I}+\mathbf{J}$ - Ventilation: air movement
$\mathbf{K}$ - Artificial cooling system
L - Air humidification

Figure 8: Examples of climatic zones using different comfort limits and passive strategies: north-east India[57] (a), Nepal [29] (b) and Brazil [14] (c) 


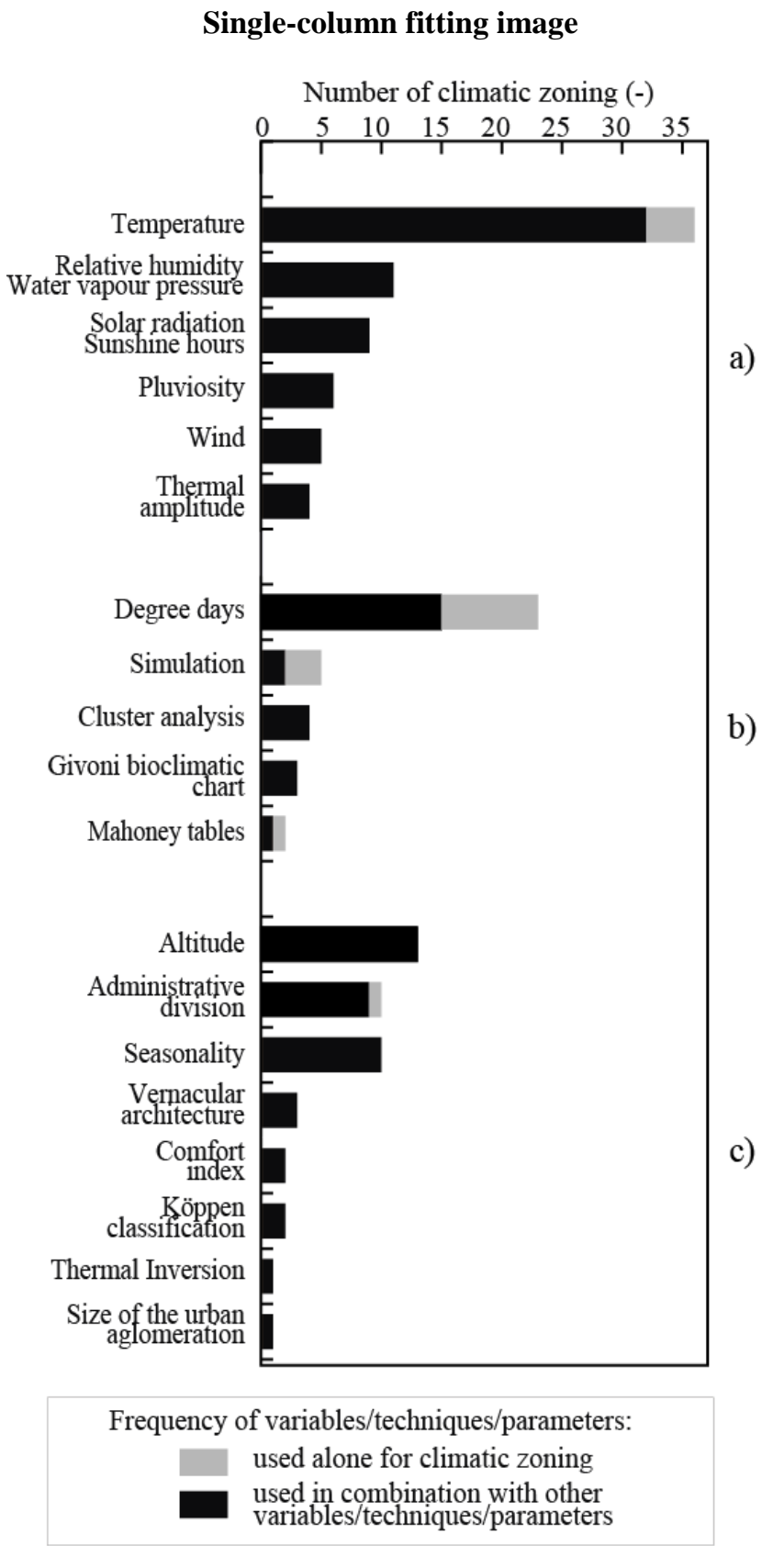

Figure 9: Frequency of usage in climatic zoning methodologies: climatic variables (a), techniques for energy assessment and climate data processing used for climatic zoning (b) and other parameters(c) 
a)

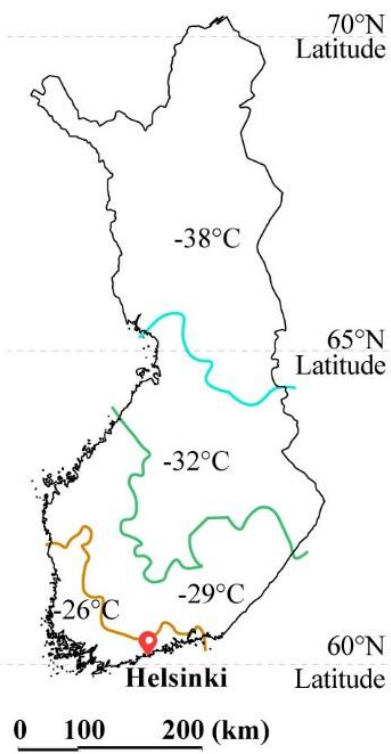

b)

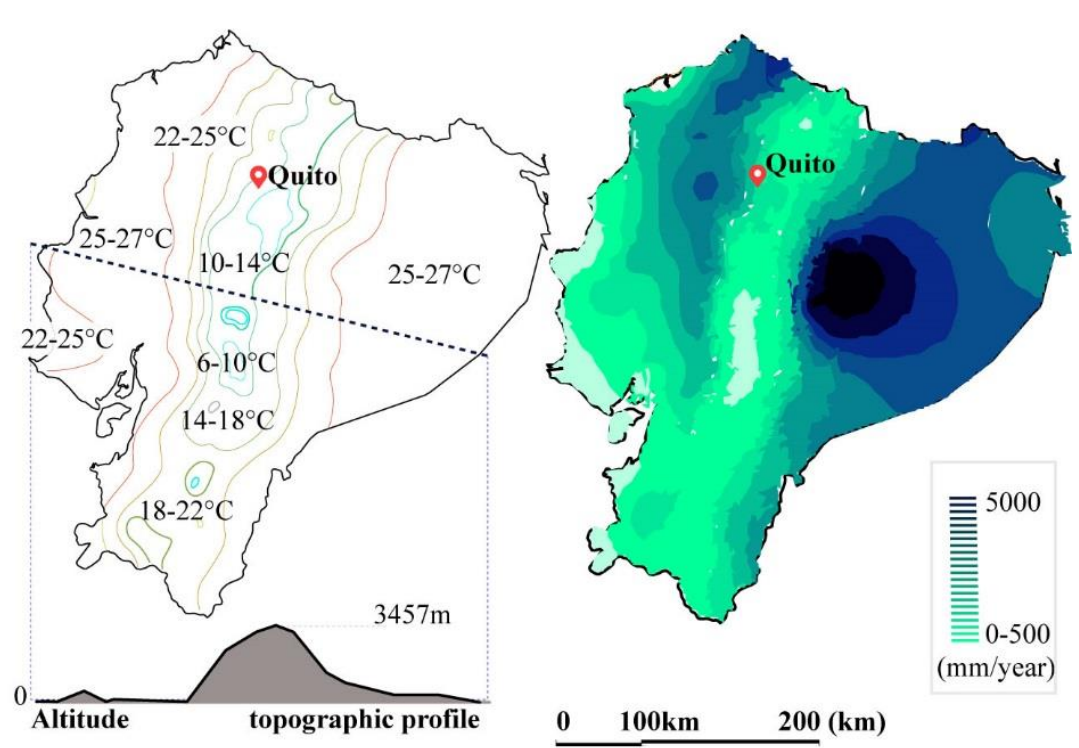

Figure 10: Climatic zoning from Finland (a) [49] and Ecuador (b) [30], annual rainfall intensity in Ecuador (c)

2-column fitting image

a)

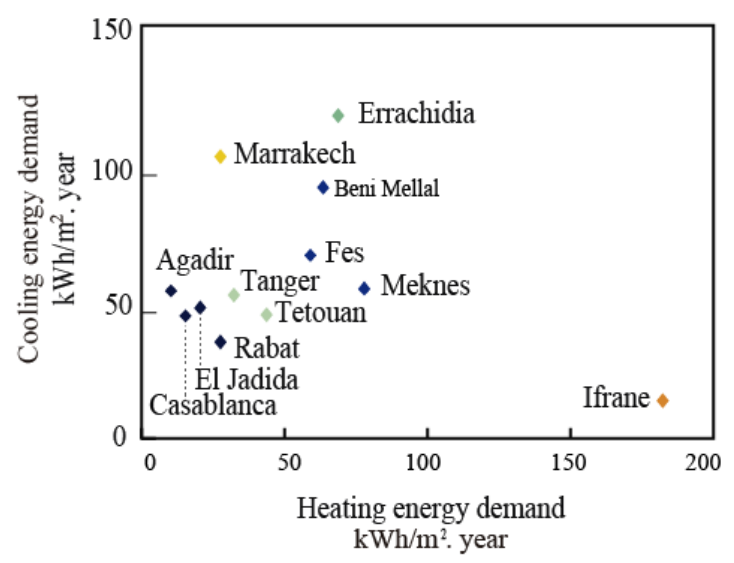

b)

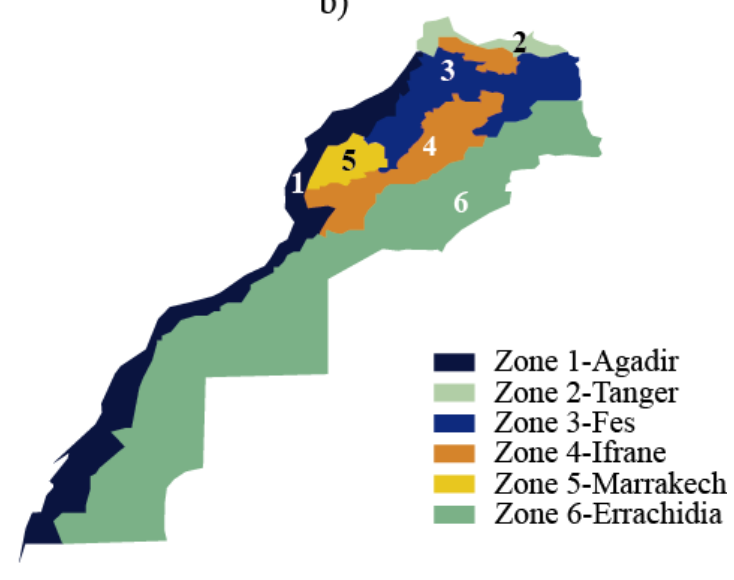

Figure 81: Correlation between heating and cooling energy demand in 12 cities of Morocco (a) Climatic zones map from Morocco (b) [20] 


\section{5-column fitting image}

a)

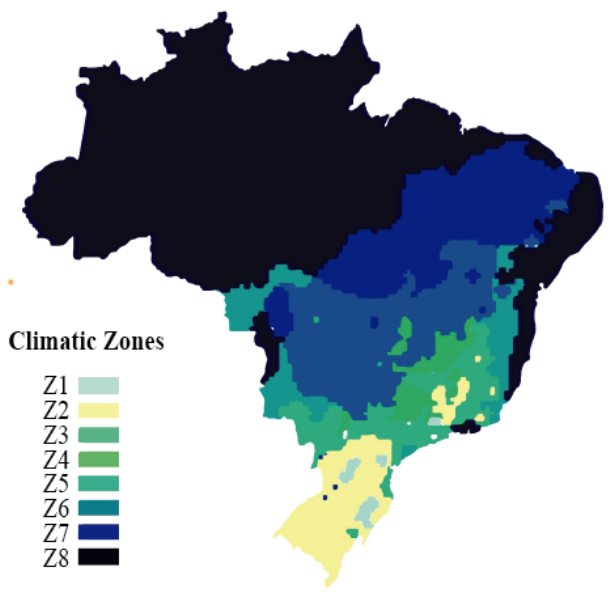

b)

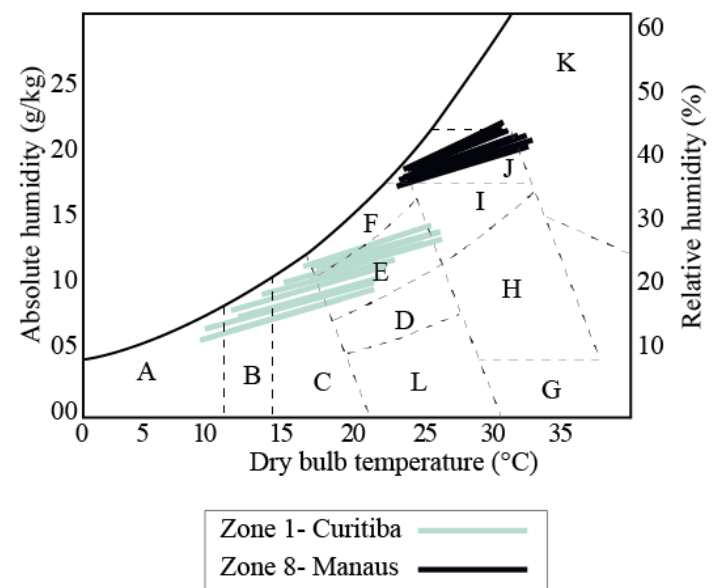

Strategies for thermal conditioning
A - Heating
B - Solar heating
C - Thermal mass for heating
D - Thermal comfort zone (low humidity)
E - Thermal comfort zone

F - Deshumidification

$\mathbf{G}+\mathbf{H}$ - Evaporative cooling

$\mathbf{H}+\mathbf{I}$ - Thermal mass for cooling

$\mathbf{I}+\mathbf{J}$ - Ventilation

K - HVAC

L - Humidification

Figure 92: Brazilian climatic zoning (a), bioclimatic chart showing examples of climates from zone 1 and 8 (b) [45]

\section{Single-column fitting image}

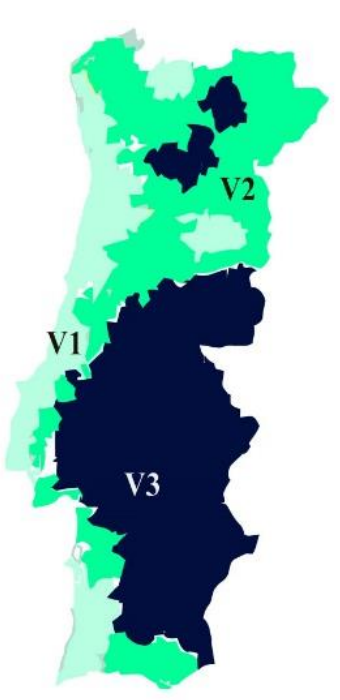

Winter
climatic zones
V1
V2
V3

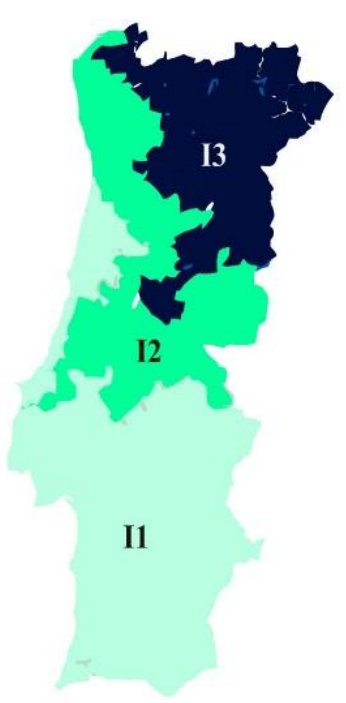

Summer

climatic zones

I1

12

Figure 103: Portugal's example of seasonality in climatic zoning [95] 
Single-column fitting image

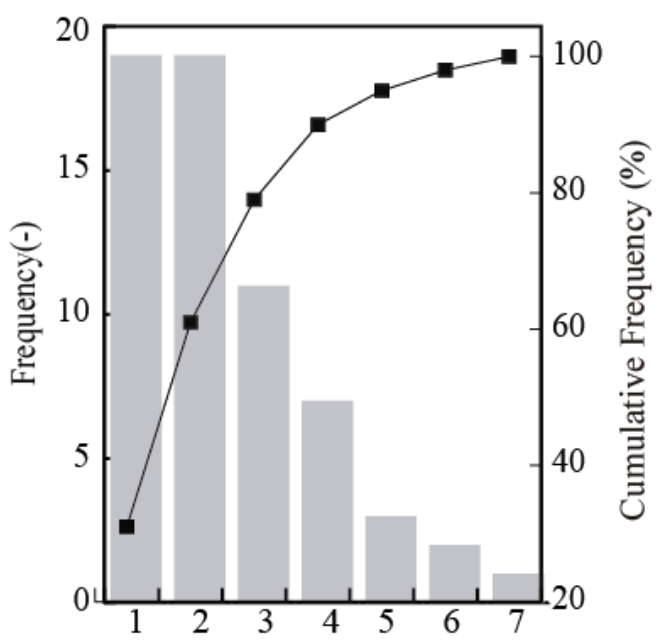

Number of parameters, variables and techniques for building assessment used simultaneously (-)

Figure 114: Frequency distribution of the number of parameters, variables and techniques for building assessment used simultaneously in each climatic zoning 